\title{
Inhibition of omeprazole induced hypergastrinaemia by SMS 201-995, a long acting somatostatin analogue in man
}

\author{
J L Meijer, J B M J Jansen, L F S J Crobach, I Biemond, C B H W Lamers
}

\begin{abstract}
Whether the long acting somatostatin analogue SMS 201-995 (octreotide, Sandostatin) could inhibit the basal and meal stimulated hypergastrinaemia and hyperpepsinogenaemia induced by omeprazole was investigated. Eight healthy subjects were randomised to receive five day courses of SMS 201-995 (25 $\mu \mathrm{g}$ subcutaneously three times daily), omeprazole (40 $\mathrm{mg}$ once a day), a combination of both drugs, or placebo. Basal and meal stimulated serum gastrin and basal serum pepsinogen $A$ and $C$ values were measured the day before treatment, on day five of treatment, and the day after each course of treatment. Omeprazole caused significant increases in basal and meal stimulated peak and integrated serum gastrin values and pepsinogen $A$ and $C$ levels, which were still significantly raised the day after stopping omeprazole treatment. Giving SMS 201-995 with omeprazole significantly reduced any omeprazole induced increases in basal and meal stimulated peak and integrated serum gastrin levels; serum pepsinogen $A$ and $C$ values were significantly inhibited too. Serum gastrin values during combined therapy were not significantly different from those during placebo treatment, whereas pepsinogen $A$ and $C$ levels were still significantly raised. On the day after stopping combined therapy, basal and meal stimulated peak and integrated serum gastrin and serum pepsinogen C (but not pepsinogen A) levels were not significantly different from values obtained on the day after stopping omeprazole alone. SMS 201-995 without omeprazole significantly inhibited basal and meal stimulated peak and integrated serum gastrin levels. Pepsinogen A was also significantly inhibited by SMS 210-995, but the reduction in pepsinogen $C$ failed to reach statistical significance. In conclusion, SMS 201-995 prevents basal and meal stimulated increases in serum gastrin during omeprazole therapy. This finding may have clinical importance in the few patients who have pronounced hypergastrinaemia because of profound long acting acid inhibition.

(Gut 1993; 34: 1186-1190)
\end{abstract}

Treatment of patients with the Zollinger-Ellison syndrome, ${ }^{12}$ peptic ulcer disease, ${ }^{34}$ and reflux oesophagitis ${ }^{56}$ with the $\mathrm{H}^{+} / \mathrm{K}^{+}$-ATPase antagonist, omeprazole, has resulted in considerably faster healing and higher healing rates than with $\mathrm{H}_{2}$ receptor antagonists. This improvement results from more profound inhibition of gastric acid secretion. ${ }^{78}$ Profound acid inhibition, however, results in increases in serum gastrin because of interference in the feedback mechanism between intragastric acidity and antral gastrin release. ${ }^{910}$ In rats, the hypergastrinaemia induced by long term omeprazole has resulted in enterochromaffin-like (EC-like) cell hyperplasia and, subsequently, gastric carcinoid formation. ${ }^{11} 12$ Further studies have shown that these effects are not restricted to omeprazole treatment, but are also found during treatment with other $\mathrm{H}^{+} / \mathrm{K}^{+}$-ATPase inhibitors and high dose $\mathrm{H}_{2}$ receptor antagonists, suggesting that the effects are secondary to profound, long term acid inhibition. The finding that the effect of omeprazole on the EC-like cells is prevented by antrectomy points to a crucial role for hypergastrinaemia in EC-like cell hyperplasia and carcinoid formation. Hypergastrinaemia in patients with type $\mathrm{A}$ atrophic gastritis and the Zollinger-Ellison syndrome is also accompanied by an increased incidence of gastric carcinoid tumours. ${ }^{13-15}$ Although carcinoid tumours have not been observed during long term omeprazole treatment, the possibility that long term pronounced hypergastrinaemia may increase the risk of tumour formation cannot be excluded. Since it has been shown in rats that decreased somatostatin concentrations in the antral mucosa may be involved in the development of hypergastrinaemia during potent acid inhibition, ${ }^{16-18}$ we have studied whether administration of the long-acting somatostatin analogue SMS 201-995 (Sandostatin, octreotide) can prevent omeprazole induced hypergastrinaemia in man. Because serum pepsinogen $\mathrm{A}$ and $\mathrm{C}$ levels are considerably increased during omeprazole treatment, ${ }^{19}{ }^{20}$ the effect of SMS 201-995 on serum pepsinogen $A$ and $C$ levels was also investigated.

\section{Methods}

Eight healthy volunteers (six men and two women; median age 33 years, range $27-43$ years) were randomly treated with SMS 201-995 (25 $\mu \mathrm{g}$ subcutaneously three times a day), omeprazole (40 mg orally once a day), a combination of omeprazole $40 \mathrm{mg}$ once daily and SMS 201-995 (25 $\mu \mathrm{g}$ three times daily), or placebo for five days. Basal and postprandial serum gastrin concentrations and basal pepsinogen $A$ and $C$ values were measured the day before, the last day (day five) of treatment, and on the day after the various courses of treatment. In studies on the last day of treatment, fasted subjects took their morning dose of study medication half an hour before eating the standard test meal, whereas on the day before and after the treatment courses placebo was given 30 minutes before eating the 


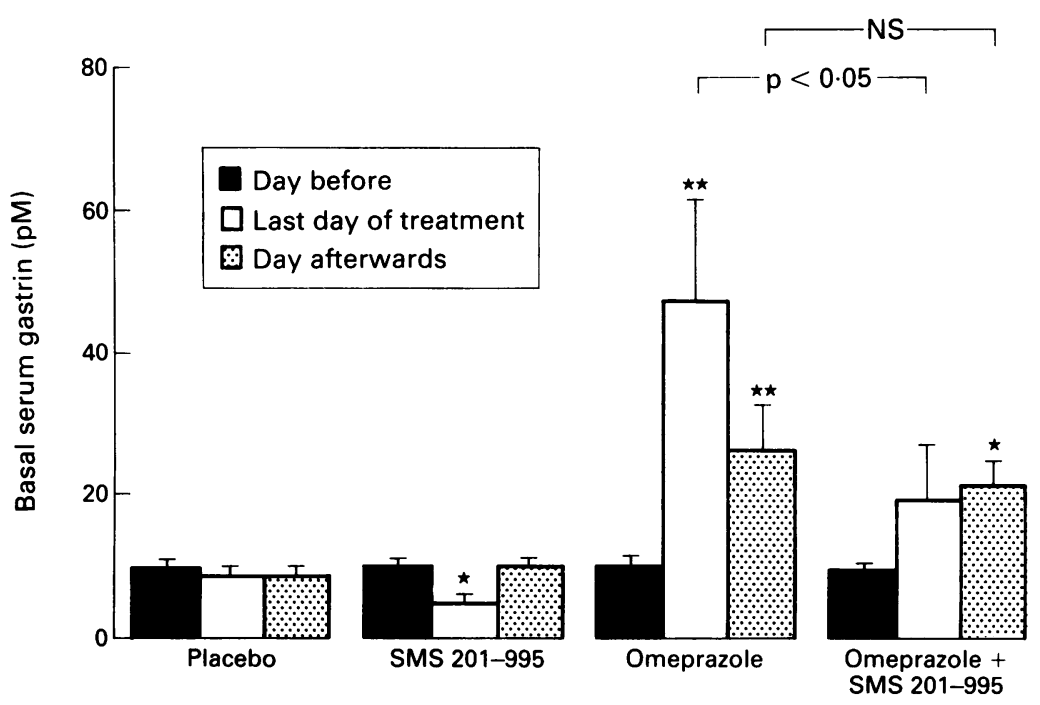

Figure 1: Effect of five days' treatment with placebo, SMS 201-995 (25 $\mu \mathrm{g}$ thrice daily) omeprazole (40 mg once daily), and omeprazole (40 mg once daily) plus SMS 201-995 (25 $\mu \mathrm{g}$ thrice daily) on basal serum gastrin (mean (SEM)) before treatment, on the last day of treatment and the day afterwards in eight healthy volunteers. Asterisks denote significant differences from placebo treatment $\left({ }^{\star} p<0.05 ;{ }^{\star} p<0.02 ; N S=\right.$ not significant $)$.

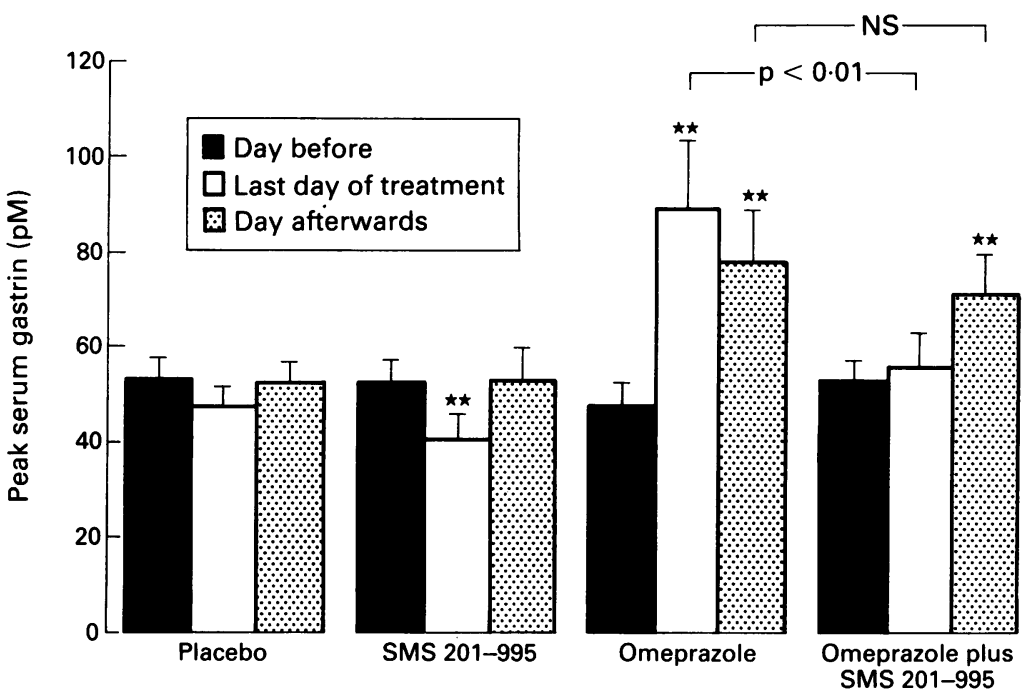

Figure 2: Effect of five days' treatment with placebo, SMS 201-995 (25 $\mu \mathrm{g}$ thrice daily), omeprazole (40 $\mu \mathrm{g}$ once daily), and omeprazole (40 mg once daily) plus SMS 201-995 (25 $\mu \mathrm{g}$ thrice daily) on postprandial peak serum gastrin (mean (SEM)) before treatment, on the last day of treatment, and the day afterwards in eight healthy volunteers. Asterisks denote significant differences from placebo treatment $\left({ }^{\star} p<00.02 ; N S=\right.$ not significant $)$.

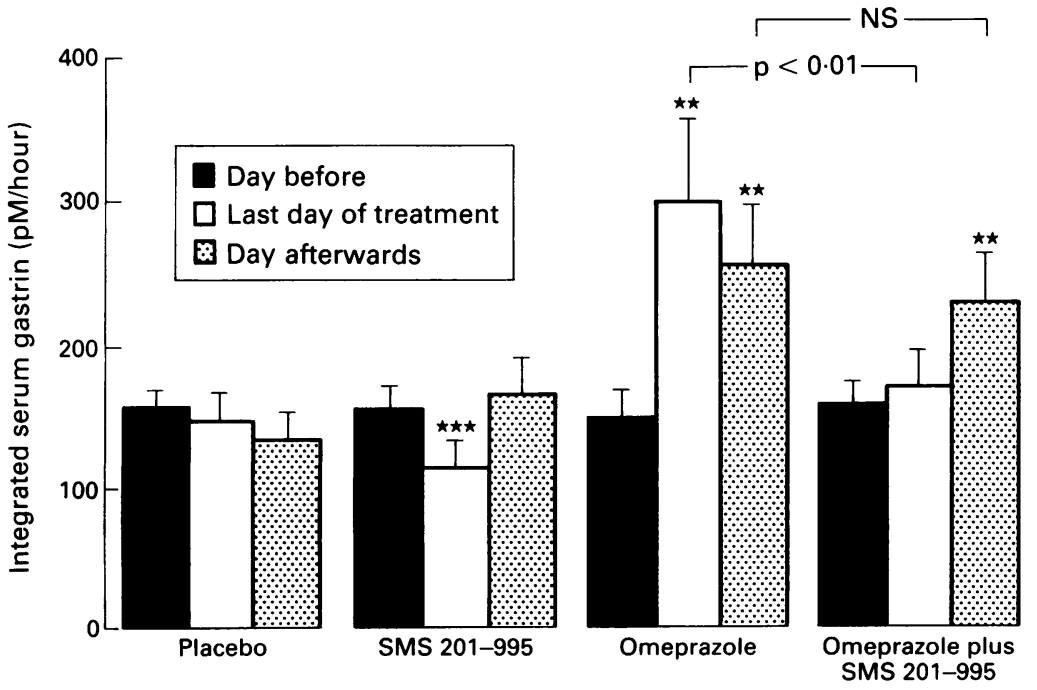

Figure 3: Effect of five days' treatment with placebo, SMS 201-995 (25 $\mu$ g thrice daily), omeprazole (40 mg once daily), and omeprazole (40 mg once daily) plus SMS 201-995 (25 $\mu \mathrm{g}$ thrice daily) on integrated postprandial serum gastrin secretion (mean (SEM)) before treatment on the last day of treatment, and the day afterwards in eight healthy volunteers. Asterisks denote significant differences from placebo treatment $\left({ }^{\star}{ }^{\star} p<0 \cdot 02 ; \star \star \star p<0.01 ; N S=\right.$ not significant $)$. test meal. There was an interval of at least one week between the treatment courses. Serum gastrin was measured twice before with an interval of 15 minutes and at 15 minutes intervals for one hour after eating a standard test meal of one slice of white bread, one boiled egg, $150 \mathrm{ml}$ of milk, $150 \mathrm{ml}$ of yoghurt, $50 \mathrm{~g}$ of cheese, $20 \mathrm{~g}$ of sugar, and $25 \mathrm{~g}$ of butter. Serum pepsinogen $\mathrm{A}$ and $C$ concentrations were measured only in the basal samples, because it has been shown that feeding does not change these. Serum gastrin was measured by a sensitive and specific radioimmunoassay, as previously described. ${ }^{21}$ The upper limit of normal in this assay is $40 \mathrm{pM}$. Serum pepsinogen $A$ and $C$ concentrations were also measured by sensitive and specific radioimmunoassays as previously described. ${ }^{22}$ In 201 healthy blood donors, the mean (SEM) pepsinogen A concentration was $59(28) \mu \mathrm{g} / \mathrm{l}$, and pepsinogen $C$ was 15 (12) $\mu \mathrm{g} / \mathrm{l}^{22}$ All samples were measured in duplicate in the same assay.

Results are expressed as mean (SEM). The basal values reported are the means of the two basal values obtained with a 15 minute interval. Integrated meal stimulated serum gastrin outputs were determined by calculating the area under the serum concentration time curve. Statistical analysis was performed by Student's $t$ test for paired results. P Values of below 0.05 were considered to be statistically significant. The study was approved by the local ethical committee and informed consent was obtained from all volunteers.

\section{Results}

\section{SERUM GASTRIN}

During placebo treatment basal, postprandial peak, and integrated serum gastrin values were similar on the three study days and on the days before each drug course.

During the placebo experiments basal serum gastrin was 10 (1) pM, meal stimulated serum gastrin values peaked at 54 (4) pM, while integrated meal stimulated serum gastrin responses were calculated to be 157 (13) pM/hour (Figs $1-3)$. When measured on day five of omeprazole medication, the basal serum gastrin concentration was significantly increased to 47 (14) pM $(\mathrm{p}<0.02)$, meal stimulated peak serum gastrin concentration to $89(14) \mathrm{pM}(\mathrm{p}<0.02)$ and integrated meal stimulated serum gastrin responses to 300 (55) $\mathrm{pM} /$ hour $(\mathrm{p}<0.02)$ (Figs 1-3). On the day after the last ingested omeprazole dose, basal serum gastrin $(26(6) \mathrm{pM})$, meal stimulated peak serum gastrin $(78(10) \mathrm{pM})$, and integrated meal stimulated serum gastrin concentrations $(255$ (40) $\mathrm{pM} /$ hour $)$ were still significantly $(\mathrm{p}<0.02)$ higher than corresponding values during placebo treatment, but the values were not significantly different from the corresponding values on day five of omeprazole treatment (Figs 1-3).

SMS 201-995 significantly inhibited basal serum gastrin levels from 10 (1) pM to 5 (1) pM $(p<0.05)$, peak serum gastrin levels after the meal from 54 (4) pM to 41 (5) pM (p<0.02), and integrated meal stimulated serum gastrin secretion from 157 (13) pM/hour to 115 (18) pM/hour $(\mathrm{p}<0 \cdot 01)$. On the day after the SMS 201-995 
treatment, basal serum gastrin values (10 (1) $\mathrm{pM})$, peak serum gastrin levels in response to the meal (53 (7) pM), and integrated meal stimulated serum gastrin responses ( 166 (24) pM/hour) were not significantly different from corresponding values during placebo treatment (Figs 1-3).

Omeprazole plus SMS 201-995 significantly reduced basal serum gastrin levels compared with those obtained during single omeprazole treatment from 47 (14) $\mathrm{pM}$ to 19 (7) $\mathrm{pM}$ $(\mathrm{p}<0.05)$, and these values were not significantly different from basal values during placebo. Peak serum gastrin values in response to the meal and integrated meal stimulated serum gastrin responses on day five of omeprazole treatment (89 (14) pM and 300 (55) pM/hour, respectively) were also significantly $(\mathrm{p}<0.01)$ reduced by SMS 201-995 (56 (7) pM and 169 (23) pM/hour, respectively), but values were not significantly different from the placebo experiments (53 (4) $\mathrm{pM}$ and 157 (13) pM/hour, respectively). One day after omeprazole plus SMS 201-995, basal $(21$ (3) $\mathrm{pM})(\mathrm{p}<0.05)$, peak $(71$ (8) $\mathrm{pM})$

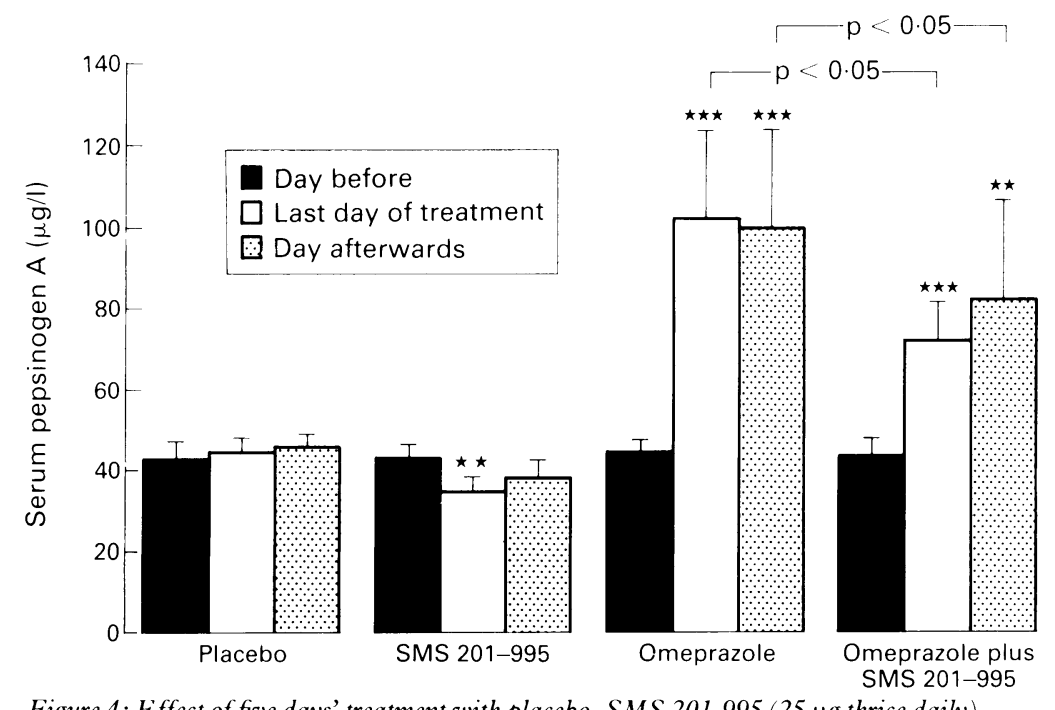

Figure 4: Effect of five days' treatment with placebo, SMS 201-995 (25 $\mathrm{g}$ thrice daily), omeprazole (40 mg once daily), and omeprazole (40 mg once daily) plus SMS 201-995

(25 $\mu \mathrm{g}$ thrice daily) on basal serum pepsinogen A values (mean $(S E M))$ before treatment, on the last day of treatment, and the day afterwards in eight healthy volunteers. Asterisks denote significant differences from placebo treatment $\left({ }^{\star} p<0 \cdot 02 ; \star \star \star p<0 \cdot 01\right)$.

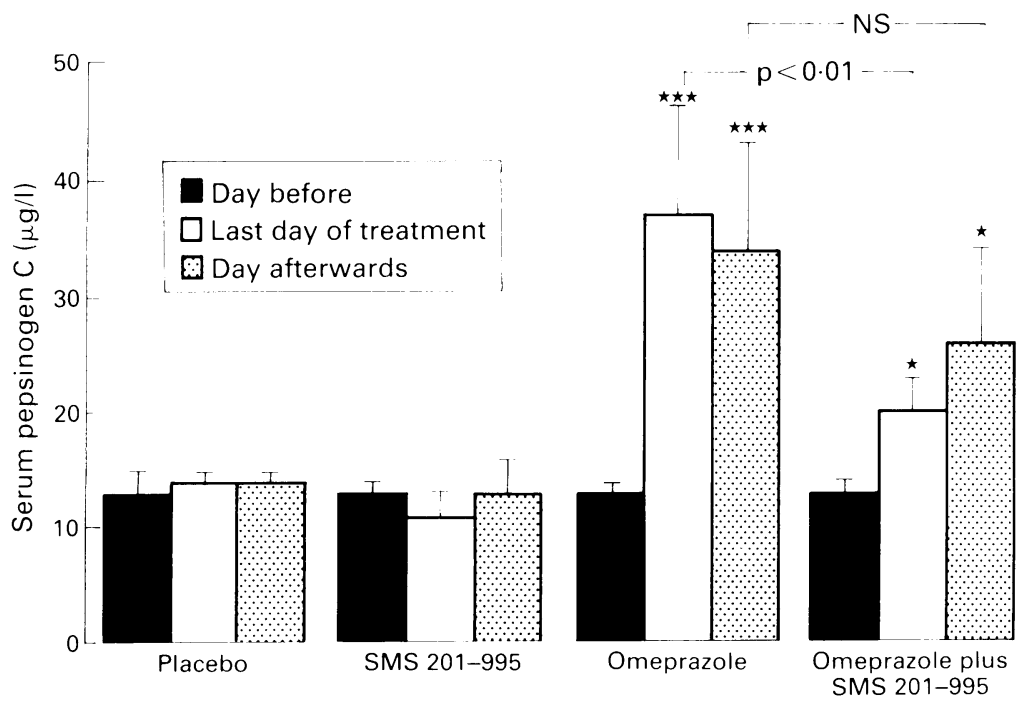

Figure 5: Effect of five days' treatment with placebo, SMS 201-995 (25 ug thrice daily) omeprazole (40 mg once daily), and omeprazole (40 mg once daily) plus SMS 201-995 (25 11 omeprazole (40 mg once daily), and omeprazole (40 mg once daily) plus SMS 201-995 (25 1,
thrice daily) on basal serum pepsinogen $C$ (mean (SEM)) before treatment, on the last day of treatment, and the day afterwards in eight healthy volunteers. Asterisks denote significant differences from placebo treatment $\left({ }^{\star} p<0.05 ;{ }^{\star \star \star} p<0 \cdot 01 ; \mathrm{NS}=\right.$ not significant $)$. $(\mathrm{p}<0.02)$, and integrated $(229$ (31) $\mathrm{pM} /$ hour $)$ $(\mathrm{p}<0.02)$ serum gastrin responses to the meal were significantly increased compared with corresponding values during placebo treatment, but the results did not differ from corresponding values on the day after omeprazole medication alone (Figs 1-3).

\section{SERUM PEPSINOGEN A AND C}

Fasting serum pepsinogen $\mathrm{A}$ and $\mathrm{C}$ levels before and after placebo and active treatment courses are shown in Figures 4 and 5. Omeprazole treatment significantly increased the fasting serum pepsinogen A level from 44 (3) $\mu \mathrm{g} / \mathrm{l}$ to 102 $(21) \mu \mathrm{g} / \mathrm{l}(\mathrm{p}<0 \cdot 01)$, and the serum pepsinogen $\mathrm{C}$ value increased significantly from 13 (1) $\mu \mathrm{g} / \mathrm{l}$ to $37(9) \mu \mathrm{g} / \mathrm{l}(\mathrm{p}<0.01)$. One day after treatment the pepsinogen $\mathrm{A}(100(23) \mu \mathrm{g} / \mathrm{l})$ and pepsinogen C levels (34 (9) $\mu \mathrm{g} / \mathrm{l})$ were still significantly increased compared with the placebo values $(p<0.01)$ SMS 201-995 treatment significantly decreased the pepsinogen A level from 43 (3) $\mu \mathrm{g} / \mathrm{l}$ to 35 (3) $\mu \mathrm{g} / \mathrm{l}(\mathrm{p}<0.02)$, while the decrease in pepsinogen $\mathrm{C}$ values failed to reach statistical significance (from 13 (1) $\mu \mathrm{g} / \mathrm{l}$ to 11 (2) $\mu \mathrm{g} / \mathrm{l}$ ). On the day after stopping SMS 201-995 treatment, these levels were not significantly decreased when compared with placebo. The combination of SMS 201-995 and omeprazole caused a significant fall in pepsinogen A from $102(21) \mu \mathrm{g} / \mathrm{l}$ to 72 (9) $\mu \mathrm{g} / \mathrm{l}(\mathrm{p}<0.05)$ compared with single omeprazole treatment; one day after stopping treatment there was still a significant rise $(\mathrm{p}<0.05)$ in the pepsinogen A value $(82(24) \mu \mathrm{g} / \mathrm{l})$. The fall in serum pepsinogen $\mathrm{C}$ during combined therapy $(20(3) \mu \mathrm{g} / \mathrm{l})$ was also significant $(\mathrm{p}<0 \cdot 01)$, when compared with values during omeprazole alone (37 (9) $\mu \mathrm{g} / \mathrm{l}$ ), but the result on the day after stopping failed to reach statistical significance $(26(8) v 34(9) \mu \mathrm{g} / \mathrm{l})$. The serum pepsinogen A and $\mathrm{C}$ levels on the day after stopping the combination therapy were significantly higher than placebo values $(\mathrm{p}<0.02$ and $\mathrm{p}<0.05$ respectively).

\section{SIDE EFFECTS}

Omeprazole was well tolerated. Intestinal cramps, upper abdominal discomfort, and fatty stools were noticed by five of the subjects during SMS 201-995 treatment taken either alone or with omeprazole. These complaints decreased towards the end of the treatment. The side effects were, however, mild and did not lead to withdrawal from the study.

\section{Discussion}

This study shows that the long acting somatostatin analogue SMS 201-995 given subcutaneously in a dose of $25 \mu \mathrm{g}$ three times daily can abolish hypergastrinaemia induced by five days' treatment with omeprazole ( $40 \mathrm{mg}$ once daily) in man. The possibility that the inhibition of omeprazole induced hypergastrinaemia by SMS 201-995 is a result of interference with the antisecretory effect of omeprazole is unlikely. Firstly, because SMS 201-995 is a potent inhibitor of gastric acid secretion and, secondly, 
because we have found in a separate pilot experiment that 24 hour intragastric $\mathrm{pH}$ profiles during single omeprazole treatment and treatment combined with SMS 201-995 did not differ in two subjects studied (data not shown). The dose of 40 $\mathrm{mg}$ omeprazole once daily is higher than that recommended for peptic ulcer therapy, but is regularly used in reflux oesophagitis, while a duration of five days was chosen because it has been shown that the effect of omeprazole on gastric acid and serum gastrin stabilises after three days of treatment. ${ }^{1920}$ SMS 201-995 was administered three times daily at eight hour intervals, to obtain optimal efficacy over the 24 hour period. The dose of $25 \mu \mathrm{g}$ thrice daily is slightly lower than that usually given to patients with the dumping syndrome, ${ }^{23}$ or neuroendocrine tumours. ${ }^{24-26}$ The relatively short duration of action of SMS 201-995 compared with omeprazole on serum gastrin was also observed in our study. The day after five days' treatment with omeprazole plus SMS 201-995, serum gastrin levels were increased because of the prolonged effects of omeprazole on gastrin release.

Several factors motivated us to study the inhibitory effects of SMS 201-995 on omeprazole induced hypergastrinaemia. Firstly, different studies have pointed to an important role for somatostatin, present in paracrine cells in the antral mucosa, ${ }^{27}$ in the regulation of gastrin release under physiological and pathophysiological conditions. ${ }^{28} 29$ Secondly, gastric somatostatin concentrations have been found to be low after long term omeprazole treatment in rats, ${ }^{3031}$ and thirdly, exogenous administration of somatostatin to hypergastrinaemic patients has been shown to inhibit significantly gastrin release. ${ }^{25} 26$

Prevention of hypergastrinaemia through potent acid inhibition may also have clinical implications, since longlasting, pronounced hypergastrinaemia in rats has been shown to stimulate EC-like cell hyperplasia and, subsequently, gastric carcinoid formation. ${ }^{112}$ Similarly, the increased incidence of carcinoid tumours found in patients with type $A$ atrophic gastritis and patients with the Zollinger-Ellison syndrome has been associated with hypergastrinaemia. ${ }^{13-15}$ It has been suggested that omeprazole treatment in patients with peptic ulcer disease will not be associated with clinically relevant EC-like cell proliferation since increases in serum gastrin in these patients are modest compared with those in patients with type A atrophic gastritis. ${ }^{72}$ However, recent studies in patients on maintenance treatment with omeprazole for reflux oesophagitis have demonstrated that about $10 \%$ achieve serum gastrin values exceeding five times the upper limit of normal. ${ }^{32-34}$ Therefore, agents capable of reducing hypergastrinaemia may be of potential value in preventing the trophic effects of hypergastrinaemia on the gastric mucosa. In omeprazole induced hypergastrinaemic rats, SMS 201-995 prevents both the development of hypergastrinaemia and the increase in the gastrin mRNA levels, ${ }^{35}$ and antagonises the trophic effect of hypergastrinaemia on the fundic endocrine mucosa. ${ }^{36}$

Giving SMS 201-995 subcutaneously, although regularly used in patients with hormone producing endocrine tumours and severe dumping syndrome, is an obvious drawback of this therapy.

Our observation that short term treatment with omeprazole increases serum pepsinogen $\mathrm{A}$ and $C$ levels confirms previous studies. ${ }^{19} 20$ Short term treatment with SMS 201-995 decreases both basal and omeprazole induced increases of serum pepsinogen $A$ and $C$ levels. This inhibition may be secondary to the inhibitory effects of SMS 201-995 on serum gastrin levels, ${ }^{20}$ but direct or other indirect effects of SMS 201-995 on the pepsinogen producing cells cannot be excluded.

In vitro studies of cells showed that somatostatin inhibits pepsinogen secretion by decreasing cyclic AMP in chief cells. ${ }^{37}$ Furthermore, treatment of rats with omeprazole leads to a decrease of somatostatin not only in the antrum but also in the fundic mucosa. ${ }^{30}{ }^{31}$ It is therefore possible that the increased serum pepsinogen concentrations during omeprazole treatment are secondary to the somatostatin deficiency of the fundic mucosa.

In conclusion, SMS 201-995 prevents basal and meal stimulated increases in serum gastrin caused by profound antisecretory therapy. This finding may be of clinical importance in the few patients who have severe hypergastrinaemia as a result of long acting profound acid inhibition.

The authors express their thanks to Mrs L T M Niepoth and Mrs $\mathrm{JW}$ van Spronsen for secretarial help and support in preparing this manuscript. The technical assistance of $\mathrm{Mr}$ I J Kuijpers who performed the serum gastrin assays is gratefully acknowledged.

1 Lamers CBHW, Lind T, Moberg S, Jansen JBMJ, Olbe L. Omeprazole in Zollinger-Ellison syndrome. Effects of a single dose and of long-term treatment in patients resistant to histamine $\mathrm{H}_{2}$-receptor antagonists. $N$ Engl $\mathcal{F}$ Med 1984; 310: 758-61.

2 Bardram L, Stadil F. Omeprazole in the Zollinger-Ellison syndrome. Scand $\mathcal{F}$ Gastroenterol 1986; 21 : 374-8.

3 Lauritsen K, Rune SJ, Bytzer P, Kelbaek H, Jensen KG, Rask-Madsen J, et al. Effect of omeprazole and cimetidine on duodenal ulcer. A double-blind comparative trial. N Engl F Med 1985; 312: 958-61.

4 Brunner G, Creutzfeldt W, Harke U, Lamberts R. Therapy with omeprazole in patients with peptic ulcerations resistant to extended high-dose ranitidine treatment. Digestion 1988; 39: 80-90.

5 Havelund T, Laursen LS, Skoubo-Kristensen E, Andersen $\mathrm{BN}$, Pedersen SA, Jensen KB, et al. Omeprazole and ranitidine in treatment of reflux oesophagitis: double blind comparative trial. $B M \mathcal{F}$ 1988; 296: 89-92.

6 Klinkenberg-Knol EC, Meuwissen SGM. Treatment of reflux oesophagitis resistant to $\mathrm{H}_{2}$-receptor antagonists. Digestion 1989; 44 (suppl 1): 47-53.

7 Lanzon-Miller S, Pounder RE, Hamilton MR, Chronos NAF, Ball S, Mercieca JE, et al. Twenty-four hour intragastric acidity and plasma gastrin concentration before and during treatment with either ranitidine or omeprazole. Aliment Pharmacol Ther 1987; 1: 239-51.

8 Lind T, Cederberg C, Ekenved G, Haglund U, Olbe L. Effect of omeprazole, a gastric proton pump inhibitor, on pentagastrin stimulated acid secretion in man. Gut 1983; 24: $270-6$

9 Walsh JH, Richardson CT, Fordtran JS. pH dependence of acid secretion and gastrin release in normal and ulcer subjects. F Clin Invest 1975; 55: 462-8.

10 Lind T, Cederberg C, Forssell H, Olausson M, Olbe L. Relationship between reduction of gastric acid secretion and plasma gastrin concentration during omeprazole treatment. Scand F Gastroenterol 1988; 23: 1259-66.

11 Carlsson E, Larsson H, Mattsson H, Ryberg B, Sundell G Pharmacology and toxicology of omeprazole, with special Pharmacology and toxicology of omeprazole, with special
reference to the effects on the gastric mucosa. Scand $\mathcal{F}$

12 Tielemans Y, Häkanson R, Sundler F, Willems G. Prolifera tion of enterochromaffinlike cells in omeprazole-treated hypergastrinemic rats. Gastroenterology 1989; 96: 723-9.

13 Borch K, Renvall H, Liedberg G. Gastric endocrine cell hyperplasia and carcinoid tumors in pernicious anemia Gastroenterology 1985; 88: 638-48.

14 Bardram L, Thomsen P, Stadil F. Gastric endocrine cells in omeprazole-treated and untreated patients with the Zollinger-Ellison syndrome. Digestion 1986; 35 (suppl 1): 116-22. 
15 Mignon M, Lehy T, Bonnefond A, Ruszniewski P, Labeille $\mathrm{D}$, Bonfils $\mathrm{S}$. Development of gastric argyrophil carcinoid tumors in a case of Zollinger-Ellison syndrome with primary hyperparathyroidism during long-term antisecretory treatment. Cancer 1987; 59: 1959-62.

16 Karnik PS, Monahan SJ, Wolfe MM. Inhibition of gastrin gene expre

17 Saffouri B, Weir GC, Bitar KN, Makhlouf GM. Gastrin and somatostatin secretion by perfused rat stomach: functional somatostatin secretion by perfused rat stomach: functional
linkage of antral peptides. Am $\mathcal{F}$ Physiol 1980; 238: G495linkage

18 Koop H, Bothe E, Eissele R, Dionysius J, Arnold R. Somatostatin - gastrin interactions in the rat stomach. Res Exp Med 1988; 188: 115-21.

19 Festen HPM, Tuynman HARE, Défize J, Pals G, Frants RR Straub JP, Meuwissen SGM. Effect of single and repeated doses of oral omeprazole on gastric acid and pepsin secretion and fasting serum gastrin and serum pepsinogen I levels. Dig Dis Sci 1986; 31: 561-6.

20 Biemond I, Crobach LFSJ, Jansen JBMJ, Lamers CBHW. Effect of short-term omeprazole administration on serum pepsinogens in relation to fasting gastrin and gastric acid secretion. Eur 7 Clin Pharmacol 1989; 37: 345-9.

21 Rehfeld JF, Stadil F, Rubin B. Production and evaluation of antibodies for the radioimmunoassay of gastrin. Scand $\mathcal{F}$ Clin Lab Invest 1972; 30: 221-32.

22 Biemond I, Jansen JBMJ, Crobach LFSJ, Kreuning J Lamers CBHW. Radioimmunoassay of human pepsinogen A and pepsinogen C. $F$ Clin Chem Clin Biochem 1989; 27: 19 25 .

23 Hopman WPM, Wolberink RGI, Lamers CBHW, van Tongeren JHM. Treatment of the dumping syndrome with the somatostatin analogue SMS 201-995. Ann Surg 1988; 207: 155-9.

24 Vinik A, Moattari AR. Use of somatostatin analog in management of carcinoid syndrome. Dig Disc Sci 1989; 34 (suppl): $4 \mathrm{~S}-27 \mathrm{~S}$

25 Maton PN, Gardner JD, Jensen RT. Use of long-acting somatostatin analog SMS 201-995 in patients with pancreatic islet tumors. Dig Dis Sci 1989; 34 (suppl): pancreatic

26 Bauer FE, Hummel M, Merki HS, Schulz E, Oeder R Marbach P. Long-acting somatostatin analog controls acid and gastrin secretion in benign, not in malignant, ZollingerEllison syndrome. 7 Clin Gastroenterol 1989; 11: 282-6.

27 Larsson L-I, Goltermann N, De Magistris L, Rehfeld JF Schwartz TW. Somatostatin cell processes as pathways for paracrine secretion. Science 1979; 205: 1393-6.

28 Arnold R, Hülst MV, Neuhof CH, Schwarting H, Becker HD, Creutzfeldt W. Antral gastrin-producing G-cells and somatostatin-producing D-cells in different states of gastric acid secretion. Gut 1982; 23: 285-91.

29 Colturi TJ, Unger RH, Feldman M. Role of circulating somatostatin in regulation of gastric acid secretion, gastrin somatostatin in regulation of gastric acid secretion, gastrin
release and islet cell function. Studies in healthy subjects and release and islet cell function. Studies in healthy subjects
duodenal ulcer patients. $\mathcal{F}$ Clin Invest $1984 ; 74: 417-23$.

30 Allen JM, Bishop AE, Daly MJ, Larsson H, Carlsson E, Polak JM, Bloom SR. Effect of inhibition of acid secretion on the regulatory peptides in the rat stomach. Gastroenterology 1986; 90: $970-7$.

31 Koop H, Willemer S, Steinbach F, Eissele R, Tuch K, Arnold $R$. Influence of chronic drug-induced achlorhydria by substituted benzimidazoles on the endocrine stomach in rats. Gastroenterology 1987; 92: 406-13.

32 Lamberts R, Creutzfeldt W, Stöckmann F, Jacubaschke K, Maas S, Brunner G. Long-term omeprazole treatment in man: effects on gastric endocrine cell populations. Digestion 1988; 39: 126-35.

33 Jansen JBMJ, Klinkenberg-Knol EC, Meuwissen SGM, de Bruijne JW, Festen HPM, Snel P, et al. Effect of long-term
treatment with omeprazole on serum gastrin and serum treatment with omeprazole on serum gastrin and serum
group $\mathrm{A}$ and $\mathrm{C}$ pepsinogens in patients with reflux group A and C pepsinogens in patients

34 Koop H, Klein M, Arnold R. Serum gastrin levels during long-term omeprazole treatment. Aliment Pharmacol Therap 1990; 4: 131-8.

35 Brand JS, Stone D. Reciprocal regulation of antral gastrin and somatostatin gene expression by omeprazole-induced achlorhydria. $\mathcal{F}$ Clin Invest $1988 ; 82: 1059-66$

36 Cadiot G, Lehy T, Bonfils S. Action of somatostatin analogue SMS 201-995) on the growth-promoting effect resulting from sustained achlorhydria in rat gastric mucosa, with special reference to endocrine cell behaviour. Eur $\mathcal{f}$ Clin Invest 1988; 18: $360-8$.

37 Muller MJ, Defize J, Hunt RH. Control of pepsinogen synthesis and secretion. Gastroenterology Clinics of North America 1990; 19: 27-40. 